\title{
Instilling Entrepreneurial Mind-Set through Entrepreneurship Education: A Systematic Review of Literature
}

\author{
Mathushan P. \\ Department of Economics and Management, Vavuniya Campus of the University of Jaffna, \\ Sri Lanka \\ mathush92@gmail.com
}

\begin{abstract}
Entrepreneurship has never been more significant than at the present moment, when economies across the world encounter the challenges of economic growth, connecting the inequality gap and solving social problems. Society necessitates individuals equipped with entrepreneurial and innovative skills, attitudes and behavior. Education is one way the government can grasp to create an environment for entrepreneurship. Entrepreneurship education has generated considerable interest in recent decades. More so, entrepreneurship education fosters entrepreneurial mind-sets, behaviors and capabilities in young people enabling them to create and lead new organizations and entrepreneurship educators are hence looking for pedagogies that enable students to be exposed to multiple experiences in entrepreneurial decision-making. However, the argument on the pedagogy of entrepreneurship education still remains agnostic. The finest outcomes in entrepreneurship education are achieved when students are exposed to action-oriented experiential learning that encourages problem-solving, creativity and peer evaluation. Building upon insights from existing literature, the findings suggest that, by embracing game-based learning model for entrepreneurship education, and design thinking approach in entrepreneurship education can foster entrepreneurial mind-set. Notably, business simulation games can play in the development of entrepreneurial capabilities in undergraduate students.
\end{abstract}

Keywords: Business startups, Entrepreneurial competences, Performance, Self-employment, Knowledge, Skills, Abilities

\section{Introduction}

An entrepreneurial culture is a thrust for sustainable economic renewal and development, for the generation of new jobs and eventually for promotions in human welfare [Kengatharan, 2012, Volkmann \& Tokarski, 2009]. Societies need individuals with entrepreneurial mind-set, innovative skills and attitudes. In recent years the evolving body of academic research has addressed the effectiveness of entrepreneurship education to inspire students for self-employment and generating an entrepreneurial culture amongst them [Lekoko et al., 2012]. Ideally, education is one way the government can commit to create a positive environment for entrepreneurship. The introduction of entrepreneurship education has a revolutionary character, since it adds to the traditional vocational training of employees and academics, the entrepreneurial culture, more appropriate to the new formats of labor relations resulting from the restructuring of the world economy [Almeida \& Buzáy, 2019].
Entrepreneurship subject which generally embraces an exploration of starting and developing a business is often thought to be a likely subject for students in business management discipline. There is an evolving concern that students do not have sufficient entrepreneurial skills and competencies to startup business particularly running small and medium enterprise (SME). Students anticipate themselves as merely job seekers not job generators. Arbaugh et al. (2010) believes that the process of teaching entrepreneurship needs to be highly interactive and immersive to develop entrepreneurial skills in students.

Extension of entrepreneurship education encapsulates the confidence that entrepreneurship can be teachable and entrepreneurs can be developed [Erikson, 2003]. Entrepreneurship education positively influenced students ' learning outcomes [Rideout \& Gray, 2013]. This underpins the requirement for universities to launch entrepreneurship education which should incorporate entrepreneurial mind-set and competencies to business management and non-business management 
discipline students. Furthermore, entrepreneurship education that incorporates factors that foster creativity, innovation, self-confidence, leadership and a positive attitude towards entrepreneurship in the formative years of a learner's education are lacking [Timmons \& Spinelli, 2007]. Reaping the entrepreneurial mind-set in education that aims to teach entrepreneurship as a method that requires practice. It is broadly recognized that entrepreneurship is a vital factor for the formation of generating job opportunities, economic growth and to elicit the strength of academic institutions. Thus, entrepreneurship can be classified as an investment and is vitally important for a nation to prosper in the economy. Therefore, the underlying purpose of this article is to investigate and discuss the role of entrepreneurial education for promoting entrepreneurial mind-set among students. The paper is structured as follows, addressing the research gap, introduction to entrepreneurship education and interdiction to entrepreneurial mind-set, introducing methodologies for entrepreneurship education eventually it presents the conclusion and recommendations.

In fact, Policy formulators and economic experts have highlighted that entrepreneurship poses a vital role in eliciting economic growth and innovation [Fayolle \& Gailly, 2012, Kengatharan, 2013]. Secundo et al. (2015) epitomized that country development in the knowledge-driven economy is not determined by the generation of fresh knowledge literally by the ability to turn the knowledge into new products, and processes that stimulate economic prosperity. Research findings epitomize that entrepreneurship can be achieved through education. However, the research on the effects of entrepreneurship education still has huge gaps [Young, 1997]. Accordingly, over the decades, entrepreneurship education programs have encountered a rapid and global revelation within higher education [Fayolle \& Gailly, 2012]. Notwithstanding, most entrepreneurship studies are conducted in developed country contexts, and their findings may not be generalizable elsewhere [Solomon, 2007]. Paradoxically, the consequences originating from entrepreneurship education are still poorly understood. Other studies found evidence that the effects are negative [Oosterbeek, 2010]. Gorman et al. (1997) found that research about the effects of entrepreneurship education is still in its infancy stage.
There is still inconsistent and reasonable model of matching which type of entrepreneurship education yields which outcomes since paradigms of entrepreneurship education are diversified ranging from a causal and linear understanding of planning, through an approach which focuses on students' mindsets, to a process-related entrepreneurial and methodical approach [Rasmussen \& Fritzmer, 2016]. Therefore, reaping an entrepreneurial mindset in human capital is becoming a vital challenge.

\section{Methods}

The present study relies on the critical review of existing literature and empirical findings. Exploiting search strategies, 190 research articles were identified with regard to the concepts of entrepreneurship education and entrepreneurial mind-set. Despite, in accordance with antecedent studies, henceforth criteria were harnessed in choosing the article [Kengatharan, 2015]: (a) a peer-reviewed journal published between 1990 and the present; and (b) full text published in English. The full papers were garnered from reputed databases such as Wiley Online Library, Emerald Insight, Sage Journals, ProQuest business, Business Source Premier (EBSCOhost), Expanded Academic (Gale), Science Direct (Elsevier), ISI Web Science, the Sloan Work and Family Research Network at Boston College, and Google Scholar where a tremendous range of articles were recognized worthwhile for the aforesaid concepts. The papers were screened in the following way. Articles that seemed more than once were denied to one entry, and those that didn't deal with university entrepreneurship and entrepreneurial competencies together were eliminated.

\section{Entrepreneurship Education}

Entrepreneurship is not a new phenomenon; it has grasped increasing attention over the past decades. Today entrepreneurship is considered the essential lever to cope with the new competitive landscape [Hitt \& Reed, 2000]. Parallel to the evolution of the field of entrepreneurship we can note an increasing interest in the development of educational programs to encourage and foster entrepreneurship [Solomon, 2007]. Entrepreneurship education was pioneered by Shigeru Fijii, who started teaching in this field in 1938 at Kobe University (Japan). In 1947 Myles Mace first introduced the course in entrepreneurship in the USA at Harvard Business School [Katz, 2008]. 
Intriguingly, the first entrepreneurship course was held in 1947 at Harvard University, countless courses and programs have been developed and implemented throughout the world. literature Reviews on entrepreneurship education and of particular entrepreneurship programs [Ronstadt et al., 1988] give evidence that these programs encourage entrepreneurs to start a business.

Indeed, it is a relatively new and emerging discipline that is entering its adolescence at colleges and universities, at least in the US. The past 20 years have witnessed an enormous growth in the number of small business management and entrepreneurship courses at different educational institutions. A great number of programs are broadly termed as enterprise or entrepreneurship education, which have been carried out in schools and higher educational institutions throughout the world[Alberti et al., 2004]. As opined by Solesvik et al. (2013) university entrepreneurship education is expected to promote students to enquire about entrepreneurial mind-sets that enhance the supply of new firms by producing graduates [Hannon, 2013]. Several prior studies found a positive impact of entrepreneurship education courses or programs at universities on perceived attractiveness and feasibility of new venture initiation or even on actual startup activity [Fayolle \& Gailly, 2012, Souitaris et al., 2007]. Indeed, the traditional Higher Education Institutions prototypes are viewed as departmentled, generally in the form of a Business School model [Gibb, 2008]. Entrepreneurship education is frequently positioned in one department, with rudiments of outreach to other departments. This Business School approach evolved from the venture creation/business startup era of the late 1990s. It caters for a target audience of business and management students with an emphasis on business planning and start-up skills, and has been accused of being too narrow in overall depth and approach. Progressively, the emphasis is shifting from teaching content "about" entrepreneurship, to developing "experiential" modes of learning and preparing graduates "for" and "in" enterprise scenarios [Taatila, 2010], through simulation and emulation of professional communities of practice. Curriculum and extracurricular activity are two basic sources of learning experiences in an entrepreneurship education program, but their effect is unequal. Peterman (2003) argue that formal curriculum does not stimulate entrepreneurial intention, on the contrary, it reduces tolerance for ambiguity.

A rudimentary question within entrepreneurial education that never seems to go out of fashion is "Can entrepreneurship be taught?" It has been a rapidly growing entrepreneurship education since mid-1990 as an emergence of new economic direction by which knowledge has become a prerequisite resource for economic activities [Yu Chenh et al., 2009]. Entrepreneurship education is distinctive in that it requires a "generalists" approach versus the more traditional specialized business education programs [Hills, 1988]. Despite the increasing number of activities and courses, there is still much discussion about the scope, objectives and methodologies that should be addressed in entrepreneurship education [Fayolle \& Gailly, 2012].

Entrepreneurship education literally focuses on accelerating entrepreneurial culture and it assists entrepreneurs to recognize and pursue opportunities. Charney \& Libecap (2000) found that entrepreneurship graduates are more likely to start new businesses, have annual incomes that are higher, own more assets, and are more satisfied with their jobs. Further it is not limited to inspiring startups, innovative and new business. Entrepreneurship is a competency for everyone, stimulating youth individuals to become creative and self-confident in whatever they pursue [Gautam \& Singh, 2015]. Gartner \& Vesper (1994) evaluate the effectiveness and failure of entrepreneurship education experimentation in various countries and manifest a significant diversity of programs offered. Entrepreneurship education should be "geared toward creativity, multi-disciplinary, process-oriented approaches, and theory-based practical application [Plaschka \& Welch, 1990]. Thus, Entrepreneurship educators must find an enterprise culture which promotes entrepreneurial skills [Gibb, 2008]. Entrepreneurship studies that have entrepreneurial facets should advance skill building in the following areas: negotiation, new product development, technological innovation, opportunity recognition, new market entry, the legal requirements of new businesses, and the ability to create a linkage from vision to action [Johannisson, 1991, Mcmullan \& Long, 1987]. 


\section{Entrepreneurial Mind-set}

The concept of mindset instigates from the cognitive psychology fields. Shepherd Douglas (1997) define EM as an 'ability and willingness of individuals to rapidly sense, act, and mobilize in response to a judgment decision under uncertainty about a possible opportunity for gain'. McGrath \& MacMillan (2000) firstly defined entrepreneurial mindset as 'the ability to rapidly sense, act, and mobilize, even under highly uncertain conditions' Mindsets are not innate; they can be influenced and learned by an individual's prior knowledge and the interaction with current environment [Mathisen \& Arnulf, 2012]. Entrepreneurial mindset described by scholars as the ability to sense, act, and mobilize under uncertain conditions. Scholars have suggested that "the successful future strategists will exploit an entrepreneurial mindset and the ability to rapidly sense, act, and mobilize, even under uncertain conditions [Bolk et al., 2003].

Entrepreneurial mind-set has been comprehended in terms of traits, skills and knowledge. Prerequisite skills for successful entrepreneurs might encapsulate oral presentation, skills, interpersonal skills, and the capability to formulate and execute a solid business plan [Ronstadt, 1985]. Personal qualities such as outgoing personality, leadership skills, self-reliant, innovativeness and the ability to engage in risk-taking [Martin \& Staines, 1994] and behavioral qualities such like a huge picture perspective, recognizing business opportunities, commitment, seeing need for control, having the conscious mind of what is right, deal with uncertainty, using contacts and connections and embracing competence considered as entrepreneurial competencies [Mitton, 1989]. The ability to be dynamic, flexible, and selfregulating in one's cognitions given dynamic and uncertain task environments [Haynie et al., 2010].

Other definitions of entrepreneurial mindset existing in the literature vary but the common point of them is that entrepreneurial mindset is a way of thinking or an ability to capture entrepreneurial opportunities in an uncertain situation. As opined by Mitchelmore \& Rowley (2010) entrepreneurship competency, develop skills and ability clusters which were identical to those in management and leadership theory. Notwithstanding, two new skills appeared; opportunity and self-management studies [Chandler \& Jansen, 1992, Herron \&
Robinson Jr., 1993]. Declarative entrepreneurship knowledge, procedural entrepreneurship knowledge, knowledge about oneself as entrepreneurial skills, marketing skills, resource skills, opportunity skills, interpersonal skills, learning skills, strategic skills, marketing, strategy, resource acquisition, opportunity identification/creation, learning skills, interpersonal skills, leadership skills, collaborative skills, creativity.

Mitchelmore \& Rowley (2010) developed a competency model that represent the following competencies.

Cognitive and non-cognitive mind-set encapsulates resource acquisition skills, opportunity identification/creation, learning skills, market niche/product innovation, idea generation, environmental scanning, recognizing and envisioning taking advantage of opportunities, and formulating strategies for taking advantage of opportunities. Moreover, there are many scholars made a consideration on these competencies [Chandler \& Jansen, 1992, Maresch et al., 2016, Man \& Lau, 2000, Volkmann \& Tokarski, 2009].

Business and management mind-set incorporates development of the management system necessary for the long term, functioning of the organization, acquisition and development of resources required to operate the firm, business operational skills, Previous involvement with start-ups, managerial experience, familiarity with industry, financial and budgeting skills, previous experience, management style, marketing skills, technical skills, Industry skills, business plan preparation, goal setting skills, and management skills [Chandler \& Hanks, 1994, Man \& Lau, 2000, McGregor \& Tweed, 2001].

Human relations mind-set encompasses the ability to develop organizational culture, delegation skills, motivate individual and in groups, hiring skills, human relations skills, and Leadership skills [Brinckmann \& Hoegl, 2011, Herron \& Robinson Jr., 1993].

Conceptual and relationship mind-set comprises conceptual competencies, organizational skills, interpersonal skills, the ability to manage customers, mental ability to coordinate activities, written and oral communication skills, decision making skills, analytical skills, logical thinking skills, deal-making skills and commitment competencies [Man \& Lau, 2000]. 
It has been recognized that four components of an entrepreneurial mindset: alertness to opportunity, risk propensity, ambiguity tolerance, and dispositional optimism [Cui et al., 2019]. Entrepreneurial mindset can be improved through training and can be considered as a mind habit that requires learning to shape [Schmidt \& Ford, 2003].

\section{Conceptual linkage of entrepreneurship education and entrepreneurial mind-set}

In the last few years, research in entrepreneurship has begun to look at the education issue more deeply but still in a very fragmented way. Young (1997) suggests that there are two sets of reasons why students may want to study entrepreneurship: first, they may want to start up their own business; second, they may wish to acquire knowledge which will be helpful in their careers in larger organizations. Alberti et al. (2004) highlight that entrepreneurship education is crucial for enhancing entrepreneurial skills, attitudes, and behaviors that foster economic growth of the country. Further entrepreneurship education in universities has a positive impact on attitude towards entrepreneurship and turns foster entrepreneurship as a meaningful and respectable career prospect for graduates [Galloway \& Brown, 2002].

Notwithstanding, Souitaris et al. (2007) revealed that extracurricular activities like guest speakers, business plan competitions, and entrepreneurship incubator projects are incentives to the motivation of entrepreneurship. It has been found that curricular and extra-curricular education have an unbalanced impact on university students, and that formal courses and extracurricular activities have moderate roles in the formation of entrepreneurial intention and other competences [Arranz et al., 2017]. More so, entrepreneurship programs offer social interactions with other participants, lecturers, and mentors, participants enhance perceptions that entrepreneurship is also a socially desirable career path [Smith \& Woodworth, 2012]. Entrepreneurship education takes many different forms including curricular courses and extracurricular activities and serves different purposes in undergraduate level. Cui et al. (2019) recommended that entrepreneurial knowledge can be acquired through theoreticaloriented activities like successful entrepreneur's speech, face-to-face communication with an en- trepreneur, conferences or workshops related to entrepreneurship, entrepreneurial spirit and values transmitted by the university or colleges, and entrepreneurial skills and competencies can be obtained through practical-oriented activities such as entrepreneurship club, entrepreneurship design competition, enterprise visit or internship, business simulations or games, entrepreneurial incubation project, and entrepreneurial activity of resourcing or networking.

Notwithstanding its claimed significance, the EM research is still embryonic [Krueger, 2017]. Existing findings on EE impact have mainly addressed EI and very few studies have examined the EE-EM link. Furthermore, it is vague how EM evolves throughout education. Intriguingly, emotional factors are fundamental for the construction of EM because affective events pose a pivotal role in entrepreneurial learning and because different educational designs can trigger affective events, which successively endorse entrepreneurial competences [Lackéus, 2014]. Nevertheless, emotional constructs are infrequent in EE research [Kyro, 2008]. A possible emotional mediator between EE and EM is entrepreneurial inspiration [Souitaris et al., 2007], a gap for EE researchers seeking the emotional drivers of EM.

The goal of most research on entrepreneurship education is to investigate the impact of entrepreneurship educational programs on individuals' intention to act entrepreneurially and the performance of the businesses created by these students subsequent to these educational programs [Patzelt, 2014]. Entrepreneurship education must furnish future entrepreneurs with the vital skills to address the need to accelerate economic development through creating new ideas and changing over those ideas into feasible and profitable businesses. Entrepreneurship education must foster entrepreneurs with the necessary skills to meet the need to generate economic development through creating new business ideas and transforming those ideas into profitable business. Entrepreneurship education incorporates all processes proposing to encourage entrepreneurial mindset, attitudes and skills and considering a wide range of elements like idea generation, creation, growth and innovation [Fayolle \& Gailly, 2012]. Students have bit or no opportunity to experience entrepreneurship practically since the programs focus more on the theoretical transfer of 
entrepreneurship knowledge than on the practical aspect [Lekoko et al., 2012]. Therefore, universities should teach students theory to supplement practical learning experience.

As cited by Solomon (2007) the actuality of entrepreneurship is the ability to visualize and develop business venture through resources from functional disciplines and ability to deal with risk and uncertainty involved in a business [Shepherd Douglas, 1997]. The positive relationship between education and business startups has been acknowledged by international literature form various viewpoint and approaches [Niyonkuru, 2005], moreover, according to researcher's point there is a viability to enhance entrepreneurial ability through education.

The fundamental purpose of education on entrepreneurship in universities is to enable the students to formulate and implement their own business with less involvement of others as soon they finish their degrees instead of waiting for the employment opportunities for a long period of time. In general, universities aim to provide an opportunity for students to acquire comprehensive knowledge and understanding about entrepreneurial mindset and orientation, sharpen students' knowledge, abilities, attitudes and competencies through entrepreneurship education, provide vast insights about formulating plans (business plan), business startups, creativity, innovation, enhance self-efficiency among students consequently, fostering advertence on entrepreneurship as a career option, make students to exploit analytical skills by utilizing real business information and situations to solve problems and make decisions, encourage students to utilize creative thought processes to solve business issues. In this sense, serious games emerge as a pertinent approach to developing entrepreneurial skills. Indeed, there is much argument about the role of education, skills and personal development within the overall sphere of enterprise and $\mathrm{HE}$ entrepreneurship. The discourse is driven by political and economic burdens concerning the ability of Higher Education Institutes (HEIs) to develop well rounded graduates that "fit" within a twenty-first century global economy [Gibb, 2008].

Taatila (2010) highlighted that key attributes of an entrepreneurial mind-set encompass perseverance, trust, determination, risk management, a positive attitude towards change, tolerance of uncertainties, initiative, the need to achieve, understanding of timeframes, creativity, an understanding of the big picture. Evolving ideas relating to entrepreneurial education are much wider than just teaching students how to develop new business plans, or create and manage business start-ups (traditional entrepreneurship education). Conversely, our argument also embraces the emphasis on pedagogical developments in experiential learning, the development of the teacherlearner experience, wider life skills and good citizenship, as vital parts of the "enterprise education" perspective [Draycott \& Rae, 2011, Jones \& Iredale, 2010]. Policy makers believe that increased levels of entrepreneurship can be grasped through education [EU, 2006] and especially entrepreneurship education. However, in Sri Lanka context this might not be the anticipated level. Crayford et al. (2012) epitomize that it is a portion of a rising ambition for education providers, students and community stakeholders to develop entrepreneurial learning opportunities based on a relational view and input from a wider variety of sources than the past. Notwithstanding, there is also a strong emphasis on moving creative ideas into action which encompasses soldier community relations and employer partnerships as part of entrepreneurial learning and strategy-making.

EM fosters individuals to conceive and act entrepreneurially because it reinforces successful forthcoming strategies [Covin, 2006]. In general, the foundation of EM lies in cognitive adaptability which is pivotal to reap required outcomes following entrepreneurial action. EM is narrowly associated recognition of opportunity, which deceives at the core of entrepreneurship and defines entrepreneurial success. Connecting the association between EE and EM would thus contribute to a deeper understanding on the scope and extent of EE impact. One of the crucial tasks is to confirm whether EE can absolutely impact the reaping students' EM [Maresch et al., 2016].

\section{Conclusion and Recommendations}

Drawing on the conceptual insights, findings of the study suggests that, typically, schools and universities should promote entrepreneurship education as a career option and enforce entrepreneurship expertise and experiences among students, undergraduates, and master's degree students. Lucidly, the transforming academic 
culture is a generic hazard, which encapsulates the entrepreneurial thinking, fear of start-ups, traditional teaching methodologies and so forth. More specifically, the emergence of ICT has a significant impact on developing entrepreneurial mind-set among students and graduates. Thus, schools and universities can foster in expanding entrepreneurial culture through ICT platforms.

An individual Entrepreneurial Mindset should encapsulate action-orientation, innovativeness (presumably discontinuous), resilience to adversity/optimism, persistence at goal-directed behaviors, domain-specific self-efficacy (possibly general self-efficacy), role identity (mental prototypes), entrepreneurial intensity, tolerance for ambiguity and uncertainty, risk-aversion (lower), future orientation (ability to delay gratification?), entrepreneurial behaviors (not just launching a venture), entrepreneurial intentions, value creation (versus opportunism), market orientation [Krueger, 2017]. Thus, there should be a course module which encapsulates developing entrepreneurial mind-set to foster the entrepreneurial thrust among the students.

Anchored in the theoretical and empirical evidence, the study confirms the needs well thought out of university entrepreneurship for developing entrepreneurial competencies.

Entrepreneurship courses should be implemented with the comprehensive understanding about the type of graduates the trainer purposes to produce. Moreover, outreach projects should be in place to affirm with the level of a desired role to the local entrepreneurial atmosphere. They identified that there has been a shift from a startup view to an attitude -changing perspective of entrepreneurship education. This entrepreneurial education has become imperative accompanied with the demand with the students searching business education that can offer the essential skills to succeed in an exponentially growing and complex management environment. Therefore, incorporating entrepreneurial competencies in entrepreneurship education in universities help students to enhance and practice new skills corresponding with entrepreneurship and new business startups and eventually, that would foster entrepreneurial spirit and growth.

Therefore, the emerging generation of entrepreneurship educators must avoid the paradigm paralysis that has consumed so many business disciplines. Cui et al. (2019) opined that entrepreneurship education poses many different methods comprising curricular courses and extracurricular activities and serves different purposes in undergraduate level. Johannisson (1991) identified five elements in entrepreneurial learning: know-why, know what, know-how, know-who and know-when and suggested a basic distinction between theoretical-oriented learning (e.g. 'know what', 'know-why') and practical-oriented learning (e.g. 'know-how', 'know-who') in entrepreneurship education.

Entrepreneurial learning has been described as the process of learning to discover and exploit opportunities [Draycott \& Rae, 2011] and can be considered a form of action learning. A number of authors argue that action learning is an effective pedagogic approach in developing and improving new ventures [Stewart \& Hitt, 2012] or at least using experiential learning to develop entrepreneurial traits.

In further, universities can provide an ideal environment for training and development of entrepreneurial competencies and core skills thus, students can reinforce their generic skills such like proactive thinking, creativity and innovation, critical thinking, analytical skills, conceptual skills, interpersonal skills, decision making skills and so forth that dramatically impact on business startup. Lucidly, entrepreneurship training needs a nontraditional approach whereby students must learn to embrace the challenges of operating in a business environment that favors creativity and risk taking. Moreover, technical training to acquire technical competencies, presentation, discussions and highly interactive classroom sessions can be conducted to develop a special training record book that can be maintained to keep training records and progress of the students is reviewed continuously. Students are referred to various surveys in order to get first hand experiences on business and business startups. A lecturer can be appointed for every student for mentoring. Make students responsible to meet the mentor regularly.

Leadership in entrepreneurial venturing success raised many questions on the specific competencies that enable individuals to lead entrepreneurial activities. Therefore, developing leadership skill for entrepreneurs can be taken into account. Eventually, not only must students be exposed 
to a business education that emphasizes multidisciplinary skills but they must participate in an "entrepreneurial experience. The students can put on their course knowledge, exercise their analytical skills, learn to communicate effectively, exploit their negotiation skills, working collaboratively in teams, compliance with legislation, and harness creative through processes to eradicate business problems. Students can also learn new business start-ups troubles like writing business plans, obtaining business loan as a startup capital. Through this "entrepreneurial experience" the students developed entrepreneurial competencies.

Entrepreneurship should provide students with the chance to grasp transferable skills that can be harnessed in any firm context, and there should transcend a narrow focus on business startup [CIHE/NCGE/NESTA, 2008]. Definite efforts are also being focused at encouraging innovative activities and in refining innovative capabilities. It should be considered the crucial factors that play a key role within $\mathrm{EE}$, such as the contents of courses, pedagogical methods, teaching models and learning experience. The pedagogy should encapsulate relevant techniques like running a real business, visiting business location and interviewing entrepreneurs. These teaching techniques might be considered as the most vital in enhancing their entrepreneurial awareness and mind-set.

\section{Game based learning}

Innovative pedagogical approaches such as game-based learning (Gamification), which provide an immersive environment, are especially well suited for entrepreneurship education [Ahn, 2008]. Game-based learning is an evolving pedagogy that carries together the emerging nature of young learners and experiential learning. Williams (2015) suggests that the business simulation endorsed students to confront their limitations, overcome some of them and make significant progress in their learning. Using SimVenture improved students' appreciation of business in general and the challenges entrepreneurs have to face in running a business. Business simulation game, SimVenture, develops not only students' business and management skills but also their entrepreneurial attitude and values. Game-based learning combines the benefits of traditional teaching and learning (that is, lectures and tutorials).

\section{Business simulation games}

Business simulation games are currently being used to teach a broad range of business and management disciplines. Business games generate a dynamic environment that presents a series of decision-making activities. Every cycle creates a new situation with a new problem to solve or decision to make. Simulations not only construct a nearly 'real world' experience but also help to bring theory and practice together by developing the ability to use acquired knowledge and skills [Williams, 2015].

\section{Design thinking Approach}

Design thinking process was proposed by the Stanford School and the HPI School of Design Thinking. It involves six interdependent phases: understand, observe, define, ideate, prototype and test. Daniel \& Ellis-Chadwick (2016) further revealed that the DT process has now become a trend in management and new product development fields, but its use in the context of entrepreneurship education is rather new. The 'understand' phase refers to a team effort to gather and use information in order to understand a certain problem domain and so to become more knowledgeable about the nature of the problem in question [Lugmayr et al., 2014]. In the 'observe' phase, team members interact with potential users with the aim of engaging with their conception of reality and examining their problems, habits, attitudes and needs. Based on the results of the previous phases, the team is now in a position to define the problem or aspect of the problem they wish to concentrate on. In the 'ideation' phase, the team starts to develop solutions, ideas and proposals, using various techniques to enhance creativity. Some of these ideas and proposals can then be taken to the 'prototype' phase, in which mock-ups are produced. These are then tried out in practice in the 'test' phase to evaluate possible solutions [Lugmayr et al., 2014].

\section{FLIGBY}

FLIGBY is a serious game that was originally developed with the objective of simulating the business management process and the application of Flow Theory in a business context [Almeida \& Buzáy, 2019]. FLIGBY appeared in the market as a serious game integrating three dimensions: (i) learning the Flow in business; (ii) using simulation as a practical teaching tool; and (iii) including 
motivating elements as games. The objective was to provide a serious game that can be used in education and training of business, management, and entrepreneurial skills and attitudes.

\section{References}

Ahn, J. H. (2008) Application of the experiential learning cycle in learning from a business simulation game. E-Learning and Digital Media, v. 5(2), pp.146-156. DOI: 10.2304/elea.2008.5.2.146

Alberti, F., Sciascia, S. \& Poli, A. (2004) Entrepreneurship education: notes on an ongoing debate. In Proceedings of the 14th Annual IntEnt Conference, University of Napoli Federico II, Italy v. 4(7).

Almeida, F., \& Buzády, Z. (2019) Learning Entrepreneurship in Higher Education Through Flow Theory and FLIGBY Game. International Journal of Virtual and Personal Learning Environments (IJVPLE), v. 9(1), pp. 1-15. DOI: $10.4018 /$ ijvple.2019010101

Arbaugh, J. B., Desai, A., Rau, B., \& Sridhar, B. S. (2010) A review of research on online and blended learning in the management disciplines: 19942009. Organization Management Journal, v. 7(1), pp. 39-55. DOI: $10.1057 /$ omj.2010.5

Arranz, N., Ubierna, F., Arroyabe, M. F., Perez, C., \& Fdez. de Arroyabe, J. C. (2017). The effect of curricular and extracurricular activities on university students' entrepreneurial intention and competences. Studies in Higher Education, v. 42(11), pp.1979-2008. DOI: 10.1080/03075079.2015.1130030

Bolk, S., Hirschhorn, J. N., Ireland, J. S., \& Lander, E. S. (2003) U.S. Patent No. 6,642,001. Washington, DC: U.S. Patent and Trademark Office.

Brinckmann, J. \& Hoegl, M. (2011) Effects of initial teamwork capability and initial relational capability on the development of new technologybased firms. Strategic Entrepreneurship Journal, v. 5(1), pp.37-57. DOI: 10.1002/sej.106

Chandler, G. N., \& Hanks, S. H. (1994) Founder competence, the environment, and venture performance. Entrepreneurship theory and practice, v.18(3),pp.77-89. DOI: $10.1177 / 104225879401800306$

Chandler, G. N., \& Jansen, E. (1992) The founder's self-assessed competence and venture performance. Journal of Business venturing, v. 7(3), pp.223-236. DOI: $10.1016 / 0883-$ 9026(92)90028-P

Charney, A., \& Libecap, G. D. (2000) The impact of entrepreneurship education: an evaluation of the Berger Entrepreneurship Program at the University of Arizona, 1985-1999. Available at SSRN 1262343. DOI: 10.2139/ssrn.1262343

$\begin{array}{crr}\text { CIHE/NCGE/NESTA } & (2008) & \text { Developing } \\ \text { Entrepreneurial } & \text { Graduates: } & \text { Putting }\end{array}$ Entrepreneurship at the Centre of Higher Education, The Council for Industry and Higher Education, National Council for Graduate Entrepreneurship and National Endowment for Science Technology and Arts, London

Covin, J. G., Green, K. M., \& Slevin, D. P. (2006) Strategic process effects on the entrepreneurial orientationsales growth rate relationship. Entrepreneurship theory and practice, v. 30(1), pp.57-81. DOI: 10.1111/j.15406520.2006.00110.x

Crayford, J., Fearon, C., McLaughlin, H. \& Van Vuuren, W., (2012) Affirming entrepreneurial education: learning, employability and personal development. Industrial and Commercial Training. DOI: $10.1108 / 00197851211231450$

Cui, J., Sun, J. and Bell, R. (2019) The impact of entrepreneurship education on the entrepreneurial mindset of college students in China: The mediating role of inspiration and the role of educational attributes. The International Journal of Management Education, pp.100296. DOI: 10.1016/j.ijme.2019.04.001

Daniel, E., \& Ellis-Chadwick, F. (2016) Entrepreneurship and liminality: the case of selfstorage based businesses. International Journal of Entrepreneurial Behavior \& Research. DOI: 10.1108/ijebr-01-2015-0015

Draycott, M., \& Rae, D. (2011) Enterprise education in schools and the role of competency frameworks. International Journal of En- 
trepreneurial Behaviour \& Research, v. 17(2), pp.127-145. DOI: 10.1108/13552551111114905

Erikson, T. (2003) Towards a taxonomy of entrepreneurial learning experiences among potential entrepreneurs. Journal of Small Business and Enterprise Development. DOI: 10.1108/14626000310461240

European Commission. Directorate-General for Agriculture, \& Rural Development. (2006) Rural Development in the European Union: Statistical and Economic Information Report. Office for Official Publications of the European Communities.

Fayolle, A., \& Gailly, B. (2012) From craft to science: Teaching models and learning processes in entrepreneurship education. DOI: 10.1109/emr.2012.6210520

Galloway, L., \& Brown, W. (2002). Entrepreneurship education at university: a driver in the creation of high growth firms? Education + Training, ISSN: 0040-0912. DOI: 10.1108/00400910210449231

Gartner, W. B. \& Vesper, K. H. (1994). Experiments in entrepreneurship education: Successes and failures. Journal of business Venturing, 9(3), pp.179-187. DOI: 10.1016/08839026(94)90028-0

Gautam, M. K., \& Singh, S. K. (2015) Entrepreneurship education: concept, characteristics and implications for teacher education. An International Journal of Education, v. 5(1), pp.21-35.

Gibb, A. (2008) Entrepreneurship and enterprise education in schools and colleges: Insights from UK practice. International Journal of Entrepreneurship Education, v. 6(2), pp.48.

Gorman, G., Hanlon, D., \& King, W. (1997) Some research perspectives on entrepreneurship education, enterprise education and education for small business management: a tenyear literature review. International small business journal, v. 15(3), pp.56-77. DOI: $10.1177 / 0266242697153004$

Hannon, P. D. (2013) Why is the entrepreneurial university important? Journal of innovation management, v. 1(2), pp.10-17. DOI: 10.24840/2183-0606_001.002_0003
Haynie, J.M., Shepherd, D., Mosakowski, E. \& Earley, P.C. (2010) A situated metacognitive model of the entrepreneurial mindset. Journal of business venturing, v. 25(2), pp.217-229. DOI: j.jbusvent.2008.10.001

Herron, L., \& Robinson Jr., R. B. (1993) A structural model of the effects of entrepreneurial characteristics on venture performance. Journal of business venturing, v. 8(3), pp.281-294. DOI: 10.1016/0883-9026(93)90032-z

Hills, G. E. (1988) Variations in university entrepreneurship education: An empirical study of an evolving field. Journal of business venturing, v.3(2), pp.109-122. DOI: 10.1016/08839026(88)90021-3

Hitt, M. A., \& Reed, T. S. (2000) Entrepreneurship in the new competitive landscape. Entrepreneurship As Strategy: Competing on the Entrepreneurial Edge. GD Meyer and KA Heppard. DOI: 10.4135/9781452231280.n2

Johannisson, B. (1991) University training for entrepreneurship: Swedish approaches. Entrepreneurship \& Regional Development, v. 3(1), pp.67-82. DOI: 10.1080/08985629100000005

Jones, B., \& Iredale, N. (2010) Enterprise education as pedagogy. Education+ training. DOI: $10.1108 / 00400911011017654$

Katz, J. A. (2008) Fully mature but not fully legitimate: A different perspective on the state of entrepreneurship education. Journal of Small Business Management, v. 46(4), pp.550-566. DOI: $10.1111 / \mathrm{j} .1540-627 x .2008 .00256 . \mathrm{x}$

Kengatharan, N. (2012) Exploring the relationship between Psychological Characteristics and Entrepreneurial Inclination: A Case Study from Sri Lanka. Global Journal of Management and Business Research, v. 12(21), pp. 83-89.

Kengatharan, N. (2013) Structuring Latent Nature of Planning Competencies of Business Operators and its Impact on Business Performance: Evidence from Sri Lanka. IJAR-BAE, v. $2(2)$, pp. 1-13.

Kengatharan, N. (2015) The nature of work family conflict: A review and agenda for future research. Int J Human Resour Stud, v. 5(2), pp.163-188. DOI: 10.5296/ijhrs.v5i2.7630 
Krueger, N. F. (2017) Is Research on Entrepreneurial Intentions Growing? Or Just Getting Bigger?. In Revisiting the entrepreneurial mind, Springer, Cham, pp. 35-40. DOI: 10.1007/978-3-319-45544-0_3

Kyro, P. (2008) A theoretical framework for teaching and learning entrepreneurship. International journal of business and globalisation, v. 2(1), pp.39-55. DOI: 10.1504/ijbg.2008.016133

Lackéus, M. (2014) An emotion based approach to assessing entrepreneurial education. The International Journal of Management Education, v. 12(3), pp.374-396. DOI: 10.1016/j.ijme.2014.06.005

Lekoko, M., Rankhumise, E. M., \& Ras, P. (2012) The effectiveness of entrepreneurship education: What matters most?. African Journal of Business Management, v. 6(51), pp.1202312032. DOI: $10.5897 /$ ajbmx12.001

Lugmayr, A., Stockleben, B., Zou, Y., Anzenhofer, S., \& Jalonen, M. (2014) Applying "design thinking" in the context of media management education. Multimedia Tools and Applications, v.71(1), pp.119-157. DOI: s11042013-1361-8

Man, T. W., \& Lau, T. (2000) Entrepreneurial competencies of SME owner/managers in the Hong Kong services sector: A qualitative analysis. Journal of Enterprising Culture, v. 8(3), pp.235-254. DOI: s0218495800000139

Maresch, D., Harms, R., Kailer, N., \& WimmerWurm, B. (2016) The impact of entrepreneurship education on the entrepreneurial intention of students in science and engineering versus business studies university programs. Technological forecasting and social change, v. 104, pp.172-179. DOI: j.techfore.2015.11.006

Martin, G., \& Staines, H. (1994) Managerial competences in small firms. Journal of management development, v. 13(7), pp.23-34. DOI: 10.1108/02621719410063396

Mathisen, J. E., \& Arnulf, J. K. (2012) Entrepreneurial mindsets: Theoretical foundations and empirical properties of a mindset scale. DOI: 10.5465 /ambpp.2012.13739abstract

McGrath, R. G., \& MacMillan, I. C. (2000) The entrepreneurial mindset: Strategies for continuously creating opportunity in an age of uncertainty, Harvard Business Press, v 284. DOI: $10.2307 / 259188$

McGregor, J., \& Tweed, D. (2001) Gender and managerial competence: support for theories of and rogyny?. Women in Management Review. DOI: $10.1108 / 09649420110401540$

Mcmullan, W. E., \& Long, W. A. (1987) Entrepreneurship education in the nineties. Journal of Business Venturing, v. 2(3), pp.261275. DOI: 10.1016/0883-9026(87)90013-9

Mitchelmore, S., \& Rowley, J. (2010) Entrepreneurial competencies: a literature review and development agenda. International journal of entrepreneurial Behavior \& Research, v. 16(2), pp.92-111. DOI: $10.1108 / 13552551011026995$

Mitton, D. G. (1989) The compleat entrepreneur. Entrepreneurship Theory and Practice, v. 13(3), pp.9-20. DOI: $10.1177 / 104225878901300303$

Niyonkuru, R. (2005) Entrepreneurship education at tertiary institutions in Rwanda: a situation analysis (Doctoral dissertation, University of the Western Cape.

Oosterbeek, H., Van Praag, M., \& Ijsselstein, A. (2010) The impact of entrepreneurship education on entrepreneurship skills and motivation. European economic review, v. 54(3), pp. 442454. DOI: j.euroecorev.2009.08.002

Patzelt, H., Williams, T.A. \& Shepherd, D.A. (2014) Overcoming the walls that constrain us: The role of entrepreneurship education programs in prison. Academy of Management Learning \& Education, v. 13(4), pp.587-620. DOI: 10.5465 /amle.2013.0094

Peterman, N. E., \& Kennedy, J. (2003) Enterprise education: Influencing students' perceptions of entrepreneurship. Entrepreneurship theory and practice, v. 28(2), pp.129-144. DOI: 10.1046/j.1540-6520.2003.00035.x

Plaschka, G.R., \& Welch, H. P. (1990) Emerging structures in entrepreneurship education, curricula design and strategies. Entrepreneurship Theory and Practice, v. 14(3), pp. 55-71. DOI: $10.1177 / 104225879001400308$ 
Rasmussen, A., \& Fritzmer, A. (2016) From dream to reality: Learning outcomes and didactic principles for teaching entrepreneurship in Nordic schools. Nordic Council of Ministers.

Rideout, E. C., \& Gray, D. O. (2013) Does entrepreneurship education really work? A review and methodological critique of the empirical literature on the effects of universitybased entrepreneurship education. Journal of Small Business Management, v. 51(3), pp.329-351. DOI: $10.1111 /$ jsbm.12021

Ronstadt, R. (1985) The educated entrepreneurs: A new era of entrepreneurial education is beginning. American journal of small business, v. 10(1), pp.7-23. DOI: $10.1177 / 104225878501000102$

Ronstadt, R., Vesper, K. H., \& McMullan, W. E. (1988) Entrepreneurship: today courses, tomorrow degrees? Entrepreneurship theory and practice, v. 13(1), pp.7-13. DOI: $10.1177 / 104225878801300102$

Schmidt, A. M., \& Ford, J. K. (2003) Learning within a learner control training environment: The interactive effects of goal orientation and metacognitive instruction on learning outcomes. Personnel psychology, v. 56(2), pp.405429. DOI: $10.1111 /$ j.1744-6570.2003.tb00156.x

Secundo,G. Christle De Beer, C.D., Schutte,C., Passiante, G. (2015) "Mobilising intellectual capital to improve European universities competitiveness: the technology transfer offices role", Journal of Intellectual Capital. DOI: 10.1108/ JIC-12-2016-0139

Shepherd, D. A., \& Douglas, E. J. (1997) Is management education developing, or killing, the entrepreneurial spirit. In Proceedings of the 1997 USASBE Annual National Conference Entrepreneurship: The Engine of Global Economic Development, San Francisco, California.

Smith, I. H., \& Woodworth, W. P. (2012) Developing social entrepreneurs and social innovators: A social identity and self-efficacy approach. Academy of Management Learning \& Education, v. 11(3), pp.390-407. DOI: 10.5465/amle.2011.0016

Solesvik, M. Z. (2013) Entrepreneurial motivations and intentions: investigating the role of education major, Education+ Training v. 55(3), pp. 253-271. DOI: $10.2139 /$ ssrn.2624796
Solomon, G. (2007) An examination of entrepreneurship education in the United States. Journal of small business and enterprise development, v. 14(2), pp.168-182. DOI: $10.1108 / 14626000710746637$

Souitaris, V., Zerbinati, S., \& Al-Laham, A. (2007) Do entrepreneurship programmes raise entrepreneurial intention of science and engineering students? The effect of learning, inspiration and resources. Journal of Business venturing, v. 22(4), pp.566-591. DOI: 10.1016/j.jbusvent.2006.05.002

Stewart, A., \& Hitt, M. A. (2012) Why can't a family business be more like a nonfamily business? Modes of professionalization in family firms. Family Business Review, v. 25(1), pp.5886. DOI: $10.1016 /$ j.jbusvent.2006.05.002

Taatila, V.P. (2010) Learning entrepreneurship in higher education. Education+ Training. DOI: 10.1108/00400911011017672

Timmons, J. A., \& Spinelli, S. (2007) New venture creation: entrepreneurship for the 21st century. Burr Ridge. IL: Irwin.

Volkmann, C. K., \& Tokarski, K. O. (2009) Student Attitudes to Entrepreneurship. Management \& Marketing, v. 4(1).

Von Graevenitz, G., Harhoff, D., \& Weber, R. (2010). The effects of entrepreneurship education. Journal of Economic behavior \& organization, 76(1), pp.90-112. DOI; 10.1016/j.jebo.2010.02.015

Williams, D. (2015) The impact of SimVenture on the development of entrepreneurial skills in management students. Industry and Higher Education, v. 29(5), pp.379-395. DOI: $10.1108 / 00400911011017672$

Young, J.E. (1997), "Entrepreneurship education and learning for university students and practicing entrepreneurs", in Sexton, D.L. and Simlor, R.W. (Eds), Entrepreneurship 2000, Upstart Publishing, Chicago, IL.

Yu Cheng, M., Sei Chan, W., \&Mahmood, A. (2009) The effectiveness of entrepreneurship education in Malaysia. Education+ Training, v. 51(7), pp.555-566. DOI: 10.1108/00400910910992754 